\title{
Teknologi Modifikasi Cuaca untuk Mendukung Ketahanan Pangan di Indonesia -Sebuah Usulan-
}

\author{
Tri Handoko Seto, Budi Harsoyo, dan F. Heru Widodo \\ UPT Hujan Buatan BPPT \\ Email: tri.handoko@bppt.go.id
}

\begin{abstract}
Food problem for a country is a very crucial thing because food is a basic necessity for human life. Climate variability affects rice production. When climate anomalies occurred in Indonesia that resulted in prolonged drought, national rice production disrupted due to the lack of irrigation water supply. Weather Modification Technology (TMC) is a human attempt to modify the weather in order to get the weather conditions as needed. TMC implementation in Indonesia, which has been conducted since 1977 has a variety of purposes, such as rainfall enhancement to overcome the drought, as well as replenishing water reservoirs/lakes for irrigation and hydropower. TMC had applied in 2007 to increase water reserves in order to increase rice production in West Java, Central Java, East Java, and Lampung related government programs to increase national rice production by 2 million tons. At that time, TMC successfully accounted for an increase of $25 \%$. Based on that experience, TMC is proposed to be implemented in 10 top rice-producing provinces every year. TMC is expected to increase national rice production so as not necessary to import rice even make Indonesia a rice surplus.
\end{abstract}

Intisari

Masalah pangan bagi suatu negara adalah suatu hal yang sangat krusial mengingat pangan adalah kebutuhan dasar bagi kehidupan manusia. Iklim yang fluktuatif berpengaruh terhadap produksi beras. Saat terjadi anomali iklim di Indonesia yang berakibat pada kekeringan yang berkepanjangan, produksi beras nasional terganggu akibat kurangnya pasokan air irigasi. Teknologi Modifikasi Cuaca (TMC) adalah suatu upaya manusia untuk memodifikasi cuaca dengan tujuan untuk mendapatkan kondisi cuaca seperti yang diinginkan. Penerapan TMC di Indonesia yang sudah dilakukan sejak tahun 1977 memiliki berbagai tujuan, antara lain menambah curah hujan untuk mengatasi kekeringan, serta pengisian air waduk/danau untuk kebutuhan irigasi dan PLTA. TMC pernah diterapkan pada tahun 2007 untuk menambah cadangan air guna meningkatkan produksi beras di Jawa Barat, Jawa Tengah, Jawa Timur, dan Lampung terkait program pemerintah untuk meningkatkan produksi beras nasional sebanyak 2 juta ton. Pada saat itu, TMC berhasil menyumbang peningkatan sebesar $25 \%$. Berbekal pengalaman tersebut maka TMC diusulkan untuk dilaksanakan di 10 provinsi penghasil beras tertinggi nasional setiap tahun. Penerapan TMC ini diperkirakan dapat meningkatkan produksi beras nasional sehingga tidak diperlukan impor beras bahkan menjadikan Indonesia menjadi surplus beras.

\section{PENDAHULUAN}

Masalah pangan bagi suatu negara adalah suatu hal yang sangat krusial mengingat pangan adalah kebutuhan dasar bagi kehidupan manusia. Masalah pangan merupakan hak asasi manusia sebagaimana di Indonesia termuat dalam pasal 27 UUD 1945. Oleh karena itu, masalah pangan harus mendapat perhatian lebih oleh Pemerintah Indonesia karena berkaitan dengan kemaslahatan seluruh warga negara Indonesia. Berkaitan dengan masalah ketahanan pangan di Indonesia, Pemerintah Republik Indonesia saat ini tengah melaksanakan program surplus 10 juta ton beras yang ditargetkan akan terpenuhi pada tahun 2014 mendatang.

Pengaruh pemanasan global (global warming) yang mengakibatkan terjadinya perubahan iklim (climate change) telah dirasakan banyak membawa dampak negatif dengan adanya kejadian bencana yang ditimbulkan oleh anomali iklim/cuaca. The Inter-Center Working Group on Climate Change (ICWG-CC) pada tahun 2002 menyatakan bahwa produktivitas pertanian di Asia diprediksikan menurun sebesar 20\%, semakin bertambahnya frekuensi dan intensitas kejadian cuaca ekstrim menjadi penyebab utama menurunnya produktivitas pertanian. Negaranegara berkembang seperti Indonesia yang memiliki populasi penduduk miskin cukup besar, paling rentan terkena dampak perubahan iklim tersebut. Dampak negatif perubahan iklim dalam bentuk bencana banjir dan kekeringan dikhawatirkan dapat mengganggu program ketahananan pangan di Indonesia. 
Fenomena perubahan iklim (climate change) sebagai dampak pemanasan global (global warming) yang paling terasa adalah terjadinya pola musim yang tidak menentu. Lama periode musim hujan dan musim kemarau tidak lagi seimbang, dan waktunya pun tidak dapat dipastikan secara tepat. Kejadian banjir serta kekeringan akibat pergeseran musim dan berkurangnya curah hujan pada beberapa daerah di Indonesia menyebabkan besarnya potensi gagal panen.

Salah satu fakta yang menunjukkan bahwa dampak negatif perubahan iklim dapat berakibat pada terganggunya stabilitas ketahanan pangan di Indonesia adalah dengan melihat catatan impor beras nasional dari tahun ke tahun. Saat terjadi anomali iklim di Indonesia yang berakibat pada gejala kekeringan yang berkepanjangan, produksi beras nasional terganggu akibat kurangnya pasokan air irigasi. Defisit cadangan beras nasional terpaksa harus ditutup dengan langkah mendatangkan impor beras dalam jumlah yang cukup besar. Impor beras dalam jumlah tinggi pernah terjadi pada tahun 2002, 2003, 2007 dan 2011 (Tabel 1.1), dimana pada tahun-tahun tersebut umumnya merupakan tahun terjadinya El Nino di Indonesia.

Tabel 1.1. Impor beras nasional tahun 2001-2011

\begin{tabular}{|c|c|}
\hline Tahun & $\begin{array}{c}\text { Jumlah } \\
\text { (ton) }\end{array}$ \\
\hline $\mathbf{2 0 0 1}$ & $639,589.10$ \\
\hline $\mathbf{2 0 0 2}{ }^{*}$ & $1,788,422.60$ \\
\hline $\mathbf{2 0 0 3}$ & $1,429,629.60$ \\
\hline $\mathbf{2 0 0 4}$ & $232,244.10$ \\
\hline $\mathbf{2 0 0 5}$ & $188,066.50$ \\
\hline $\mathbf{2 0 0 6}$ & $437,960.10$ \\
\hline
\end{tabular}

\begin{tabular}{|c|r|}
\hline Tahun & $\begin{array}{c}\text { Jumlah } \\
\text { (ton) }\end{array}$ \\
\hline 2007* $^{*}$ & $1,405,278.50$ \\
\hline $\mathbf{2 0 0 8}$ & $285,674.10$ \\
\hline $\mathbf{2 0 0 9}$ & $244,755.50$ \\
\hline $\mathbf{2 0 1 0}$ & $687,581.50$ \\
\hline 2011* & $2,750,476.18$ \\
\hline
\end{tabular}

Catatan : * tahun El Nino

Tekad pemerintah untuk mencapai surplus beras 10 juta ton pada 2014 menghadapi tantangan yang cukup berat. Selama periode satu dekade terakhir, produksi padi nasional selalu mengalami peningkatan dari tahun ke tahun. Namun sejak tahun 2011, produksi padi mulai mengalami gejala penurunan. Dalam Tabel 1.1. terlihat bahwa menurunnya produksi padi nasional mengakibatkan nilai impor beras melonjak drastis pada tahun 2011. Itu sebabnya mulai tahun 2011 Pemerintah Republik Indonesia mulai mencanangkan program surplus 10 juta ton beras yang ditargetkan akan terpenuhi pada tahun 2014 mendatang. Angka Sementara BPS pada tahun 2011 menunjukkan penurunan produksi padi sebesar 1,10\%. Penurunan ini terjadi karena penurunan luas panen yang mencapai 52,13 ribu hektar $(0,39 \%)$, dan penurunan produktivitas sebesar 0,35 kuintal/hektar $(0,70 \%)$.

Dari seluruh uraian di atas, jelas sangat diperlukan sekali adanya upaya meminimalisir dampak negatif yang dapat ditimbulkan dari faktor iklim dan cuaca terhadap program ketahanan pangan di Indonesia. Salah satunya melalui penerapan Teknologi Modifikasi Cuaca (TMC) yang telah teruji dan kerap kali dimanfaatkan untuk upaya antisipasi dan mitigasi bencana yang disebabkan oleh faktor iklim dan cuaca di Indonesia.

Thailand, sebagai salah satu negara produsen beras dunia, telah lama memanfaatkan Teknologi Modifikasi Cuaca (TMC) dalam menunjang sektor pertaniannya. Guna mencukupi kebutuhan air irigasi bagi lahan pertaniannya, TMC dilakukan sepanjang tahun di negara tersebut, terutama saat memasuki musim kemarau. Hasilnya, produktivitas pertanian di Thailand cukup maju. TMC di Indonesia pun dalam awal sejarahnya mengadopsi dan belajar dari negara tersebut. Presiden RI saat itu (Soeharto) meminta Prof. B.J. Habibie (Menteri Riset dan Teknologi RI saat itu) untuk mengadopsi teknologi ini untuk turut memajukan sektor pertanian di Indonesia. Uraian lebih detil tentang teknologi ini akan dibahas lebih detil dalam bab tersendiri.

Berkaca dari kesuksesan sektor pertanian di Thailand, proposal ini mencoba menawarkan konsep penerapan TMC untuk menunjang ketahanan pangan di Indonesia. Proposal ini menyajikan analisis produksi pertanian secara temporal maupun spasial, analisis proyeksi curah hujan di wilayah Indonesia untuk beberapa tahun ke depan, dan juga gambaran peningkatan produksi pertanian di Indonesia dengan hasil penambahan curah hujan melalui penerapan TMC di Indonesia.

\section{TEKNOLOGI MODIFIKASI CUACA}

Secara terminologi, Teknologi Modifikasi Cuaca (TMC) atau lebih dikenal oleh orang awam dengan istilah hujan buatan adalah suatu bentuk upaya manusia untuk memodifikasi cuaca dengan tujuan tertentu agar mendapatkan kondisi cuaca seperti yang diinginkan. Disebut sebagai suatu teknologi karena memang aktivitas memodifikasi cuaca pada dasarnya merupakan suatu aplikasi yang memerlukan sentuhan teknologi dalam prosesnya. Hasil akhir dari upaya memodifikasi cuaca tersebut umumnya adalah untuk meningkatkan intensitas curah hujan di suatu tempat (rain enhancement), meski untuk tujuan tertentu dapat juga dikondisikan sebaliknya, yaitu untuk menurunkan intensitas curah hujan di suatu lokasi tertentu (rain reduction). Di negara-negara barat, khususnya di negara-negara yang berada pada daerah lintang tinggi, aktivitas modifikasi cuaca (weather modification) juga dilakukan dengan tujuan untuk mereduksi badai es (hail 
suppression).

Dalam konteks pemanasan global (global warming) yang mengakibatkan terjadinya perubahan iklim (climate change), Teknologi Modifikasi Cuaca menjadi salah satu solusi yang bisa diandalkan untuk mereduksi kerugian yang dapat ditimbulkan oleh bencana yang disebabkan oleh faktor iklim dan cuaca.

Sejarah modifikasi cuaca di Indonesia bermula dari gagasan Presiden Soeharto yang menginginkan dilaksanakannya kegiatan hujan buatan di Indonesia untuk memberikan dukungan kepada sektor pertanian di Indonesia, seperti halnya yang sudah dilaksanakan di Thailand. Gagasan tersebut direspon oleh Prof.Dr.Ing.BJ Habibie yang saat itu menjabat sebagai Menteri Negara Riset dan Teknologi dengan melakukan percobaan hujan buatan pada tahun 1977 di daerah Bogor, Sukabumi dan Solo dibawah asistensi Prof. Devakul dari Royal Rainmaking Thailand.

TMC dilakukan dengan meniru proses yang terjadi di dalam awan melalui aktivitas penyemaian awan (cloud seeding). Sejumlah partikel higroskopik yang dibawa dengan pesawat sengaja ditambahkan langsung ke dalam awan agar proses pengumpulan butiran tetes air di dalam awan segera di mulai. Pelepasannya bisa dilakukan di bawah dasar awan, atau bisa juga dilepas langsung ke dalam awan, yang penting dilakukan pada daerah up draft. Dengan berlangsungnya pembesaran tetes secara lebih awal maka hujan juga turun lebih cepat dari awan, dan proses yang terjadi lebih efektif. Awan yang dijadikan obyek penyemaian adalah jenis awan Cumullus $(\mathrm{Cu})$ yang berpotensi menjadi hujan.

Berdasarkan jenis bahan semai yang digunakan, penerapan TMC di Indonesia dapat dibagi menjadi 2 yaitu TMC Sistem Powder (menggunakan bahan semai berupa bubuk halus berdiameter sekitar $10 \mu \mathrm{m}$ ) dan TMC Sistem Flare (berbentuk padat yang dikemas dalam tabung).

Dalam konsep TMC rain enhancement yang bertujuan untuk menambah curah hujan di suatu tempat, efek keseluruhan yang terjadi pada daerah yang dilakukan TMC adalah jumlah curah hujan dalam sehari bisa menjadi lebih banyak dibandingkan dengan hujan yang turun apabila daerah tersebut tidak dilakukan TMC. Bila kegiatan pelaksanaan TMC dilakukan dalam jangka panjang misalnya 3-6 bulanan, maka curah hujan pada musim tersebut juga bertambah. Pada beberapa tempat di dunia, penambahan curah hujan dari penerapan TMC telah diteliti oleh pakar TMC, termasuk di Indonesia, yaitu sekitar 15-35\%. Ini tentu saja sangat berguna untuk pengelolaan sumberdaya air di suatu daerah.

Peran TMC dalam konteks pengelolaan sumberdaya air telah tercantum dalam UndangUndang Republik Indonesia nomor 7 Tahun 2004 tentang Sumberdaya Air dalam Pasal 38 ayat 1 , yang menyatakan bahwa "Pengembangan fungsi dan manfaat air hujan dilaksanakan dengan mengembangkan Teknologi Modifikasi Cuaca".

Penerapan TMC di Indonesia yang sudah dilakukan sejak tahun 1977 memiliki berbagai tujuan, antara lain menambah curah hujan untuk mengatasi kekeringan, pengisian air waduk/danau untuk kebutuhan irigasi dan PLTA, mengurangi curah hujan untuk mengatasi banjir dan longsor, serta mengurangi kabut asap akibat kebakaran hutan dan lahan. Sampai dengan bulan Maret 2013, penerapan TMC pada berbagai daerah di Indonesia sudah seringkali dilakukan dengan berbagai tujuan.

TMC pernah memiliki pengalaman terlibat langsung dalam upaya mendukung program ketahanan pangan nasional pada tahun 2007 dan 2012. Guna mendukung program nasional peningkatan produksi beras 2 juta ton pada tahun 2007, TMC diselenggarakan untuk menambah pasokan air irigasi pada beberapa waduk strategis di empat provinsi sentra produksi beras nasional, yaitu di Waduk Saguling, Cirata dan Jatiluhur (Jawa Barat), Waduk Gadjah Mungkur dan Kedungombo (Jawa Tengah), Waduk Sutami, Sengguruh dan Selorejo (Jawa Timur), serta Waduk Batutegi (Lampung). Berdasarkan hasil perhitungan Tim Monitoring dan Evaluasi oleh forum Masyarakat Hidrologi Indonesia (MHI), kegiatan TMC pada tahun 2007 telah menghasilkan penambahan total volume air di seluruh waduk pada keempat provinsi tersebut sebesar 703,5 juta $\mathrm{m}^{3}$, dan dengan asumsi kebutuhan air $9000 \mathrm{~m}^{3} /$ ha serta produksi beras 4 ton/ha maka hasil TMC telah memberi sumbangan sebesar 25\% dari rencana peningatan beras nasional sebesar 2 juta ton pada tahun 2007.

Pada tahun 2012, TMC juga dilakukan di DAS Citarum Jawa Barat untuk mendukung pencapaian program ketahanan pangan nasional surplus 10 juta ton beras tahun 2014, dimana Jawa Barat mendapat kuota sebesar 3 juta ton beras. Hasil TMC berhasil memberikan tambahan air di ketiga waduk kaskade Citarum (Saguling, Cirata dan Jatiluhur) sebesar 423,5 juta $\mathrm{m}^{3}$ dan dengan asumsi yang sama dengan asumsi yang digunakan dalam perhitungan serupa di tahun 2007, maka hasil TMC telah memberikan sumbangan produksi beras sebanyak 231.000 ton beras atau sekitar $7,7 \%$ dari kuota penambahan produksi beras nasional yang dibebankan kepada Provinsi Jawa Barat.

\section{PRODUKSI BERAS NASIONAL DAN CURAH HUJAN DI WILAYAH INDONESIA}

\subsection{Produksi Beras Nasional}

Sekitar $54 \%$ produksi beras nasional berasal dari Pulau Jawa. Provinsi Jawa Barat 
$(17,47 \%)$, Jawa Timur $(17,08 \%)$ dan Jawa Tengah $(15,14 \%)$ merupakan 3 provinsi teratas produsen beras nasional. Produksi beras di ketiga provinsi tersebut dalam setahun berkisar antara 911 juta ton. Distribusi spasial produksi beras di wilayah Indonesia digambarkan dalam peta pada Gambar 3.1. Berdasarkan data dari BPS, produksi beras di Indonesia sejak tahun 2006-2010 cenderung meningkat. Total produksi beras nasional pada tahun 2006 berjumlah 54,45 juta ton dan pada tahun 2010 meningkat 22\% menjadi 66,47 juta ton. Tahun 2011, produksi beras nasional sedikit mengalami penurunan sebesar 1,1\% dibanding tahun 2010 menjadi 65,76 juta ton. Data produksi beras nasional selama periode tahun 2006-2011 dapat dilihat dalam Tabel 3.1, sementara grafiknya ditampilkan dalam Gambar 3.2 .

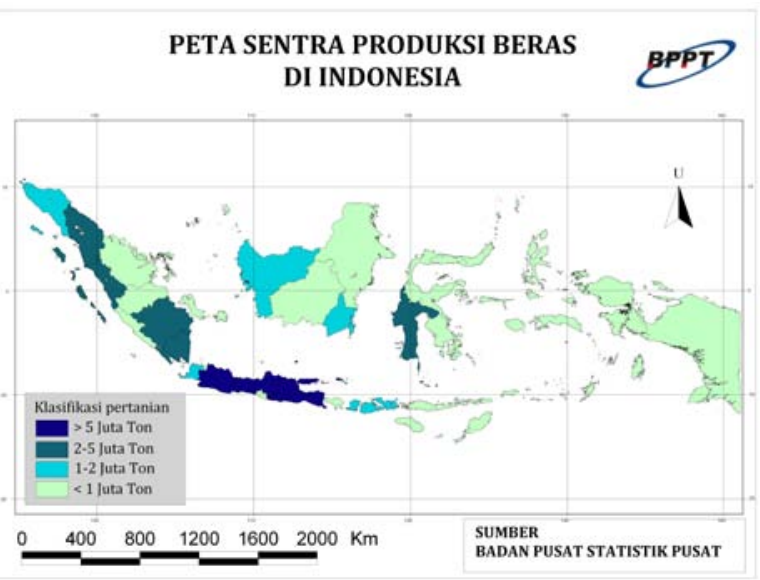

Gambar 3.1. Peta Sentra Produksi Beras di Indonesia

Tabel 3.1. Produksi beras nasional tahun 2006-2011

\begin{tabular}{|c|c|c|c|c|c|c|c|c|c|}
\hline \multirow{2}{*}{ No } & \multirow{2}{*}{ Provinsi } & \multicolumn{7}{|c|}{ PRODUKSI (Juta Ton) } & \multirow{2}{*}{$\begin{array}{l}\text { Kontribus } \\
\text { Nasional } \\
(\%)\end{array}$} \\
\hline & & 2006 & 2007 & 2008 & 2009 & 2010 & 2011 & Rerata & \\
\hline & Indonesia & 54.45 & 57.16 & 60.33 & 64.40 & 66.47 & 65.76 & 61.43 & \\
\hline 1 & Jawa Barat & 9.42 & 9.91 & 10.11 & 11.32 & 11.74 & 11.63 & 10.69 & 17.47 \\
\hline 2 & Jawa Timur & 9.35 & 9.40 & 10.47 & 11.26 & 11.64 & 10.58 & 10.45 & 17.08 \\
\hline 3 & Jawa Tengah & 8.73 & 8.62 & 9.14 & 9.60 & 10.11 & 9.39 & 9.26 & 15.14 \\
\hline 4 & Sulawesi Selatan & 3.37 & 3.64 & 4.08 & 4.32 & 4.38 & 4.51 & 4.05 & 6.62 \\
\hline 5 & Sumatera Utara & 3.01 & 3.27 & 3.34 & 3.53 & 3.58 & 3.61 & 3.39 & 5.54 \\
\hline 6 & Sumatera Selatan & 2.46 & 2.75 & 2.97 & 3.13 & 3.27 & 3.38 & 2.99 & 4.89 \\
\hline 7 & Lampung & 2.13 & 2.31 & 2.34 & 2.67 & 2.81 & 2.94 & 2.53 & 4.14 \\
\hline 8 & Sumatera Barat & 1.89 & 1.94 & 1.97 & 2.11 & 2.21 & 2.28 & 2.06 & 3.37 \\
\hline 9 & Kalimantan Selatan & 1.64 & 1.95 & 1.95 & 1.96 & 1.84 & 2.04 & 1.90 & 3.10 \\
\hline 10 & Banten & 1.75 & 1.82 & 1.82 & 1.85 & 2.05 & 1.95 & 1.87 & 3.06 \\
\hline 11 & $\begin{array}{l}\text { Nusa Tenggara } \\
\text { Barat }\end{array}$ & 1.55 & 1.53 & 1.75 & 1.87 & 1.77 & 2.07 & 1.76 & 2.87 \\
\hline 12 & Aceh & 1.35 & 1.53 & 1.40 & 1.56 & 1.58 & 1.77 & 1.53 & 2.51 \\
\hline 13 & Kalimantan Barat & 1.11 & 1.23 & 1.32 & 1.30 & 1.34 & 1.37 & 1.28 & 2.09 \\
\hline 14 & Sulawesi Tengah & 0.74 & 0.86 & 0.99 & 0.95 & 0.96 & 1.04 & 0.92 & 1.51 \\
\hline 15 & Bali & 0.84 & 0.84 & 0.84 & 0.88 & 0.87 & 0.86 & 0.85 & 1.40 \\
\hline 16 & DI Yogyakarta & 0.71 & 0.71 & 0.80 & 0.84 & 0.82 & 0.84 & 0.79 & 1.29 \\
\hline 17 & Kalimantan Tengah & 0.49 & 0.56 & 0.52 & 0.58 & 0.65 & 0.61 & 0.57 & 0.93 \\
\hline 18 & Kalimantan Timur & 0.54 & 0.57 & 0.59 & 0.56 & 0.59 & 0.55 & 0.57 & 0.92 \\
\hline 19 & $\begin{array}{l}\text { Nusa Tenggara } \\
\text { Timur }\end{array}$ & 0.51 & 0.51 & 0.58 & 0.61 & 0.56 & 0.59 & 0.56 & 0.91 \\
\hline 20 & Jambi & 0.54 & 0.06 & 0.58 & 0.64 & 0.63 & 0.65 & 0.52 & 0.85 \\
\hline 21 & Bengkulu & 0.38 & 0.47 & 0.48 & 0.51 & 0.52 & 0.50 & 0.48 & 0.78 \\
\hline 22 & Sulawesi Utara & 0.45 & 0.05 & 0.52 & 0.55 & 0.58 & 0.60 & 0.46 & 0.75 \\
\hline 23 & Riau & 0.04 & 0.49 & 0.49 & 0.53 & 0.57 & 0.54 & 0.44 & 0.73 \\
\hline 24 & Sulawesi Tenggara & 0.35 & 0.42 & 0.41 & 0.41 & 0.45 & 0.49 & 0.42 & 0.69 \\
\hline 25 & Sulawesi Barat & 0.30 & 0.31 & 0.34 & 0.31 & 0.36 & 0.37 & 0.33 & 0.54 \\
\hline 26 & Gorontalo & 0.19 & 0.20 & 0.24 & 0.26 & 0.25 & 0.27 & 0.24 & 0.39 \\
\hline 27 & Papua & 0.07 & 0.08 & 0.09 & 0.10 & 0.10 & 0.12 & 0.09 & 0.15 \\
\hline 28 & Maluku & 0.05 & 0.06 & 0.08 & 0.09 & 0.08 & 0.09 & 0.07 & 0.12 \\
\hline 29 & Maluku Utara & 0.06 & 0.05 & 0.05 & 0.05 & 0.06 & 0.06 & 0.05 & 0.09 \\
\hline 30 & Papua Barat & 0.03 & 0.03 & 0.04 & 0.04 & 0.03 & 0.03 & 0.03 & 0.05 \\
\hline 31 & Bangka Belitung & 0.02 & 0.00 & 0.02 & 0.02 & 0.02 & 0.02 & 0.02 & 0.02 \\
\hline 32 & DKI Jakarta & 0.01 & 0.01 & 0.01 & 0.01 & 0.01 & 0.01 & 0.01 & 0.01 \\
\hline \multirow[t]{2}{*}{33} & Kepulauan Riau & 0.00 & 0.00 & 0.00 & 0.00 & 0.00 & 0.00 & 0.00 & 0.00 \\
\hline & Jumlah & 54.45 & 57.16 & 60.33 & 64.40 & 66.47 & 65.76 & 61.43 & 100.00 \\
\hline
\end{tabular}




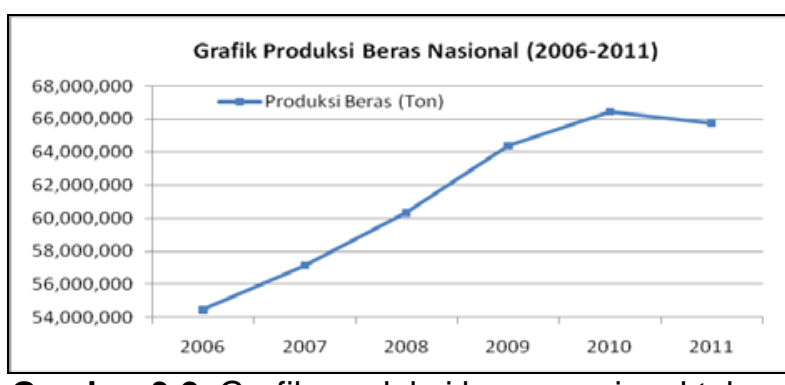

Gambar 3.2. Grafik produksi beras nasional tahun 2006-2011

Menurut Dirjen Tanaman Pangan Kementerian Pertanian, Udhoro Kasih Anggoro, dalam Seminar Nasional Mekanisasi Pertanian (2012) masih ada peluang untuk meningkatkan produksi beras dengan mengoptimalkan potensi lahan sawah seluas 6,6 juta hektar, seperti terlihat dalam Tabel 3.2.

Tabel 3.2. Potensi Lahan Untuk Padi di Indonesia

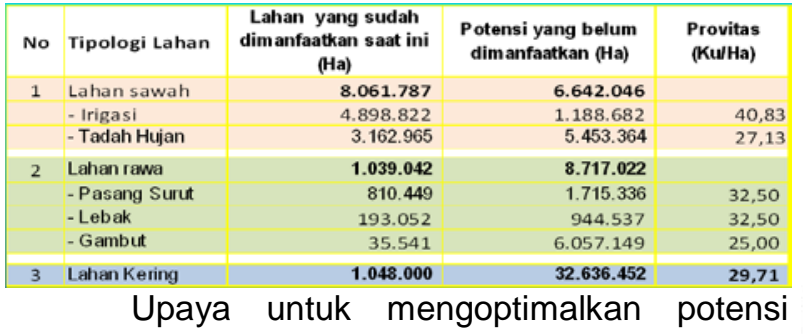
lahan sawah seperti yang dimaksud di atas adalah dengan cara menjamin ketersediaan pasokan air bagi lahan sawah irigasi maupun sawah tadah hujan pada potensi lahan yang belum termanfaatkan. Aplikasi Teknologi Modifikasi Cuaca (TMC) merupakan alternatif solusi untuk menjawab permasalahan tersebut.

Berdasarkan data provinsi penghasil beras nasional dari Tabel 3.1, kami mengusulkan agar pelaksanaan TMC dilakukan pada 10 provinsi teratas penghasil beras nasional, yaitu Jawa Barat, Jawa Timur, Jawa Tengah, Sulawesi Selatan, Sumatera Utara, Sumatera Selatan, Lampung, Sumatera Barat, Kalimantan Selatan dan Banten. Hasil pelaksanaan TMC diharapkan dapat mengoptimalkan sebagian potensi lahan sawah irigasi dan sawah tadah hujan yang belum termanfaatkan seperti tersaji dalam Tabel 3.2.

\subsection{Curah Hujan Wilayah Indonesia}

Menurut Aldrian dan Susanto (2003), iklim di Indonesia berdasarkan siklus atau variabilitas rata-rata curah hujan tahunannya terbagi atas 3 wilayah zonasi seperti tergambar dalam Gambar 3.3. Ketiga wilayah tersebut adalah zona monsoonal (region A) yang meliputi wilayah Sumatera bagian Selatan, Jawa, Bali, Nusa Tenggara, Kalimantan bagian Selatan dan
Sulawesi bagian Selatan dan sebagian wilayah Papua; zona equatorial (region B) yang meliputi Sumatera bagian Utara, Kalimantan bagian Utara; dan zona regional (region $\mathrm{C}$ ) yang meliputi Sulawesi bagian Utara dan Kepulauan Maluku. Pola dan karakteristik curah hujan pada masingmasing wilayah iklim ditunjukkan pada Gambar 3.4 .

Berdasarkan pembagian iklim ini, kesepuluh provinsi penghasil beras nasional berada pada region $A$ dan region $B$.

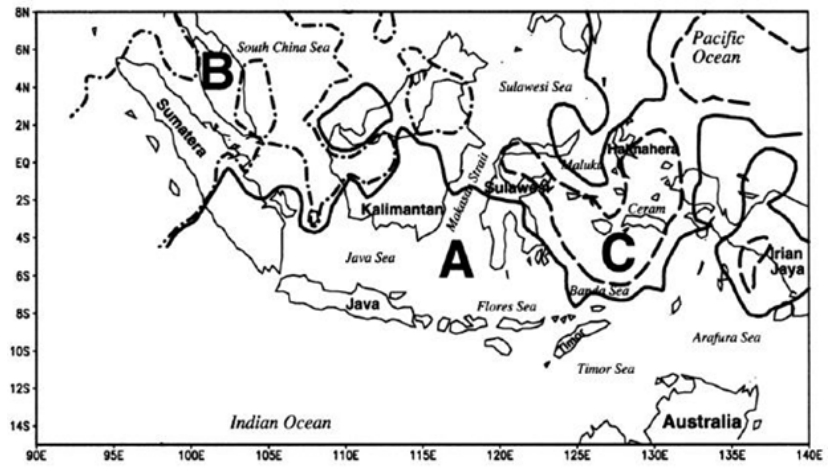

Gambar 3.3. Pembagian wilayah iklim di Indonesia berdasarkan siklus curah hujannya (sumber : Aldrian dan Susanto, 2003).
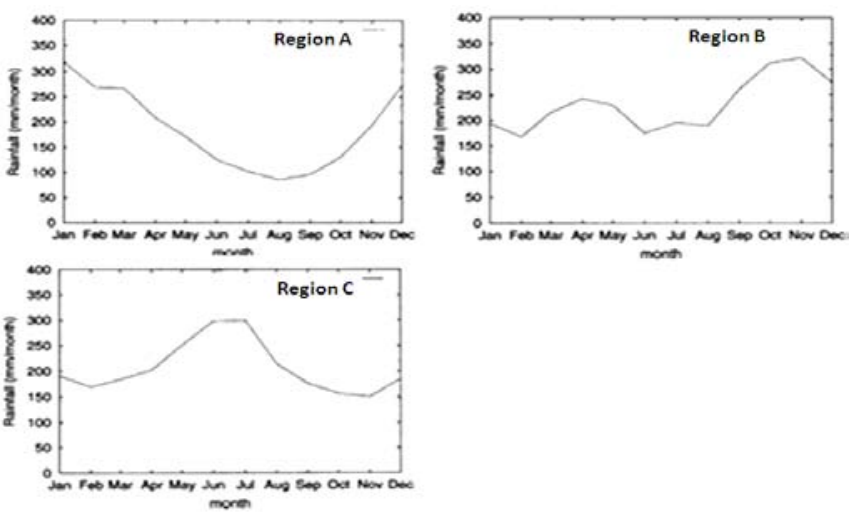

Gambar 3.4. Karakteristik curah hujan tahunan dari masing-masing wilayah iklim di Indonesia (sumber ; Aldian dan Susanto, 2003)

Dalam seminar bertemakan "Adaptasi Perubahan Iklim dan Bencana Terhadap Ketahanan Pangan Dalam Rangka Pencapaian Target Surplus Beras 10 Juta Ton Tahun 2014" yang diselenggarakan oleh Masyarakat Hidrologi Indonesia (MHI) pada bulan Maret 2012 Ialu, Kepala Badan Meteorologi, Klimatologi dan Geofisika (BMKG), Dr. Sri Woro B. Harijono, memberikan paparan tentang proyeksi distribusi curah hujan di wilayah Indonesia untuk beberapa tahun ke depan. Proyeksi curah hujan di wilayah Indonesia untuk jangka pendek sampai dengan tahun 2014 dapat dilihat pada Gambar 3.5, sedangkan untuk jangka panjang sampai dengan tahun 2039 dapat dilihat pada Gambar 3.6. 


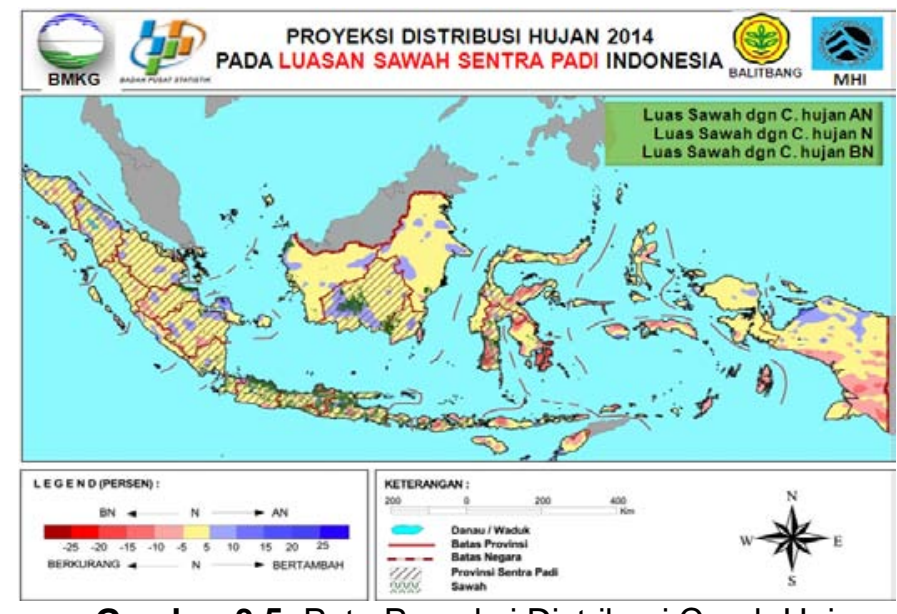

Gambar 3.5. Peta Proyeksi Distribusi Curah Hujan di Wilayah Indonesia Tahun 2014 (sumber : BMKG, 2012)

Dari Gambar 3.5 diketahui bahwa untuk kesepuluh provinsi penghasil beras terbanyak di Indonesia, sebagian besar curah hujannya diprediksi normal, kecuali untuk Provinsi Sulawesi Selatan dan sebagian kecil wilayah Pantura Jawa Tengah yang curah hujannya diprediksi berada di bawah normal. Sementara dari Gambar 3.6 diperoleh gambaran bahwa untuk jangka panjang curah hujan di sebagian besar wilayah Sumatera diprediksi berada di kisaran normal dan sedikit di atas normal, sementara untuk sebagian wilayah di Pulau Jawa dan Provinsi Sulawesi Selatan diprediksi berada di bawah normal.

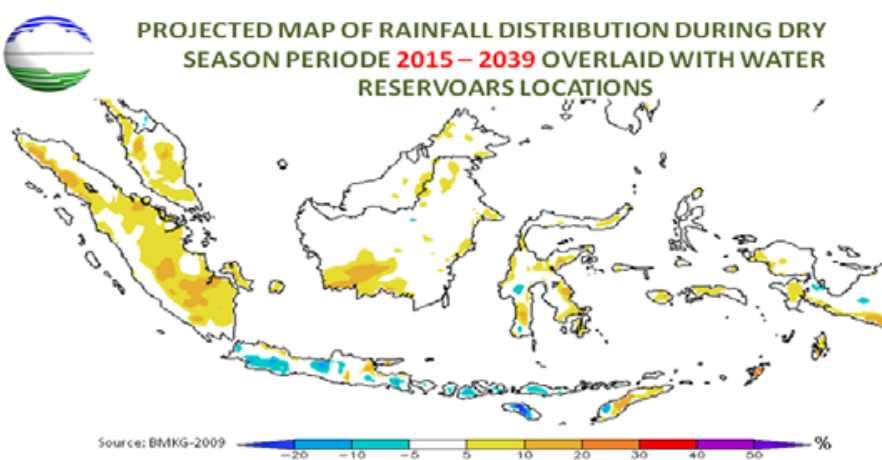

Gambar 3.6. Peta Proyeksi Distribusi Curah Hujan di Wilayah Indonesia Selama Musim Kemarau Untuk Periode Tahun 2015-2039 (sumber : BMKG, 2012)

\section{REKOMENDASI PELAKSANAAN TMC}

Dengan melihat prediksi distribusi curah hujan di wilayah Indonesia untuk beberapa tahun ke depan dan berkaca dari pengalaman pelaksanaan TMC untuk mendukung program ketahanan pangan nasional tahun 2007 dan 2012 lalu, BPPT mengusulkan pelaksanaan TMC di 10 provinsi penghasil beras terbanyak yang menjadi wilayah sentra produksi beras nasional. Tujuan dilakukannya TMC adalah untuk mengantisipasi kekeringan guna menjaga stabilitas pasokan air irigasi di sejumlah waduk strategis yang menjadi pemasok air irigasi bagi area sentra produksi pertanian.

Untuk masing-masing lokasi, pelaksanaan TMC direkomendasikan berlangsung selama 60 hari yang terbagi menjadi dua periode, masingmasing selama 30 hari untuk periode musim tanam gadu dan 30 hari untuk periode musim tanam gadu.

\subsection{Estimasi Manfaat Hasil Pelaksanaan TMC}

Dengan mengacu pada hasil penelitian dari banyak pakar bahwa hasil TMC mampu meningkatkan curah hujan sebesar 15-35\% dan ditambah dengan pengalaman pelaksanaan TMC untuk menunjang program ketahanan pangan nasional tahun 2007 di Provinsi Jawa Barat, Jawa Tengah dan Jawa Timur, diasumsikan hasil TMC mampu meningkatkan produksi beras nasional sebesar 1,8\%. Berdasarkan asumsi tersebut, maka estimasi produksi beras nasional dari 10 provinsi yang menjadi daerah target pelaksanaan TMC akan meningkat sebanyak 0,89 juta ton, atau sekitar $1,4 \%$ dari rerata total produksi beras nasional dalam satu tahun, seperti tersaji dalam Tabel 3.3.

Tabel 3.3. Estimasi peningkatan produksi beras nasional dari hasil pelaksanaan TMC

\begin{tabular}{|c|c|c|c|}
\hline \multirow[t]{2}{*}{ No } & \multirow[t]{2}{*}{ Provinsi } & $\begin{array}{l}\text { Rerata } \\
2006- \\
2001\end{array}$ & $\begin{array}{c}\text { Pening- } \\
\text { katan } \\
1,8 \%\end{array}$ \\
\hline & & \multicolumn{2}{|c|}{ (Juta Ton) } \\
\hline 1 & Jawa Barat & 10.69 & 0.19 \\
\hline 2 & Jawa Timur & 10.45 & 0.19 \\
\hline 3 & Jawa Tengah & 9.26 & 0.17 \\
\hline 4 & Sulawesi Selatan & 4.05 & 0.07 \\
\hline 5 & Sumatera Utara & 3.39 & 0.06 \\
\hline 6 & $\begin{array}{l}\text { Sumatera } \\
\text { Selatan }\end{array}$ & 2.99 & 0.05 \\
\hline 7 & Lampung & 2.53 & 0.05 \\
\hline 8 & Sumatera Barat & 2.06 & 0.04 \\
\hline 9 & $\begin{array}{l}\text { Kalimantan } \\
\text { Selatan }\end{array}$ & 1.90 & 0.03 \\
\hline 10 & Banten & 1.87 & 0.03 \\
\hline & & Jumlah & 0.89 \\
\hline
\end{tabular}

Dengan asumsi harga standar beras Bulog tahun 2012 sebesar Rp.6.600,00/kg, maka jika hasil produksi beras secara keseluruhan dalam Tabel 3.3 tersebut dikonversikan dalam nominal rupiah kira-kira setara dengan nilai :

$=890.000 .000 \mathrm{~kg} \times$ Rp. $6.600,00$

$=$ Rp.5.874.000.000.000,00 


\subsection{Kebutuhan Pesawat Untuk Operasional TMC}

Dalam menunjang operasional pelayanan TMC kepada para pengguna jasanya, saat ini BPPT memiliki 5 unit pesawat yang terdiri atas 4 unit pesawat Casa 212-200 dan 1 unit pesawat Piper Chayene II. Dari kelima pesawat yang dimiliki oleh UPT Hujan Buatan BPPT, 3 unit berbasis bahan semai powder, 1 unit berbasis bahan semai liquid dan 1 unit berbasis bahan semai flare. Dari segi umur, kelima pesawat tersebut sudah berusia tua dan perlu peremajaan. Pesawat termuda (CASA, PK-TLG) telah berusia 20 tahun dan pesawat tertua (PIPER CHAYENNE II, PK-TMC) telah berusia 24 tahun.

Kelima pesawat milik UPT Hujan Buatan BPPT tersebut dalam operasionalnya dikelola secara bersama antara BPPT dengan pihak operator swasta dalam bentuk kerjasama operasional pesawat. Pada saat tidak dipakai oleh UPT Hujan Buatan BPPT untuk kegiatan pelayanan jasa TMC, kelima pesawat tersebut dioperasikan oleh pihak operator swasta untuk melayani penerbangan perintis di sejumlah daerah. Pada saat UPT Hujan Buatan BPPT memerlukan pesawat tersebut untuk melayani permintaan jasa TMC, pihak operator swasta berkewajiban menyediakan pesawat dalam keadaan serviceable berikut dukungan kru pesawat dalam pelaksanaan operasional TMC. Hal ini dilakukan karena UPT Hujan Buatan BPPT tidak mendapatkan alokasi dana DIPA untuk kebutuhan perawatan asset pesawat yang dimilikinya. Oleh karena itu, untuk memenuhi kebutuhan biaya perawatan asset pesawat yang dimiliki, UPT Hujan Buatan BPPT menjalin kerjasama semacam ini dengan pihak operator swasta.

Dalam 2 tahun terakhir, rata-rata permintaan pelayanan jasa TMC sebanyak 10-12 kali dalam setahun. Dengan keterbatasan jumlah pesawat yang dimiliki, UPT Hujan Buatan BPPT kerap menemui kendala dalam memenuhi permintaan tersebut, terutama dari segi ketersediaan pesawat. Kendala ini lebih terasa saat permintaan tersebut datang secara berbarengan sehingga kegiatan terpaksa dilakukan di beberapa tempat secara paralel. Untuk mengatasi kendala keterbatasan pesawat, UPT Hujan Buatan BPPT mengambil langkah inisiatif melakukan kerjasama dengan pihak TNI untuk mendapatkan dukungan pesawat beserta crew guna melaksanakan operasional TMC.

Faktor usia pesawat juga menjadi kendala saat pelaksanaan operasional pesawat, karena kerap kali terjadi trouble engine dan membutuhkan waktu beberapa hari untuk perbaikan sehingga mengganggu jalannya operasional di lapangan. Selain berpotensi menggangu operasional di lapangan, faktor usia juga mengandung potensi resiko keselamatan penerbangan. Dua pesawat UPT Hujan Buatan BPPT pernah mengalami kecelakaan, yaitu PK-VSE (jatuh di Tarakan tahun 2008) dan PK-TLF (jatuh di Bohorok tahun 2011).

Untuk mendukung pelaksanaan operasi

TMC di 10 provinsi penghasil beras teratas idealnya dibutuhkan sekitar 10 unit pesawat terbang. Alokasi waktu pelaksanaan yang hampir bersamaan menyebabkan jumlah pesawat mutlak dibutuhkan untuk masing-masing provinsi secara tersendiri, tidak dapat digunakan secara bergantian.

Dengan keterbatasan jumlah pesawat yang dimiliki UPT Hujan Buatan BPPT, maka untuk rencana pelaksanaan TMC di 10 provinsi yang dijadikan daerah target TMC dibutuhkan tambahan sebanyak 7 unit pesawat terbang baru. Hal ini disebabkan karena dari 5 unit pesawat terbang yang dimiliki UPT Hujan Buatan BPPT, maksimal hanya sebanyak 3 unit yang dapat digunakan untuk operasional pelayanan TMC, sementara 2 unit pesawat lainnya tetap dipakai oleh pihak operator pesawat mitra kerja UPT Hujan Buatan BPPT untuk melayani penerbangan regular.

Berdasarkan pengalaman, jenis pesawat CASA merupakan pilihan yang paling sesuai untuk kebutuhan operasional TMC karena selain handal untuk keperluan penerbangan komersil, jenis pesawat ini memiliki kapasitas muatan angkut yang cukup banyak. Usulan penambahan pesawat terdiri atas 5 unit CASA NC 212-200 dan 2 unit CASA CN 235. Harga 1 unit pesawat CASA NC 212-200 adalah sekitar Rp.65.000.000.000,00 (enam puluh lima miliar rupiah), sementara untuk harga 1 unit pesawat CASA CN 235 adalah sekitar Rp.22.000.000.000,00 (dua puluh dua miliar rupiah), sehingga untuk membeli 5 unit pesawat CASA NC 212-200 dan 2 unit pesawat CASA CN 235 dibutuhkan biaya sekitar :

$$
\begin{aligned}
& =(5 \times \text { Rp. 65.000.000.000,00 })+(2 \times \text { Rp. } \\
& \text { 22.000.000.000,00 })
\end{aligned}
$$$$
=\text { Rp. } 325.000 .000 .000,00+\text { Rp. }
$$$$
\text { 440.000.000.000,00 }
$$$$
\text { = Rp. } 765.000 .000 .000,00
$$

Kebutuhan akan tambahan jumlah pesawat terbang kiranya bisa menjadi perhatian bagi Pemerintah Pusat yang dalam proposal ini kami sampaikan melalui Badan Perencanaan Pembangunan Nasional (Bappenas).

\subsection{Kebutuhan Biaya Pelaksanaan TMC}

Anggaran yang diperlukan untuk membiayai operasional pelaksanaan TMC guna mendukung ketahanan pangan nasional disesuaikan dengan tarif harian pelayanan jasa TMC berdasarkan Peraturan Pemerintah Republik Indonesia Nomor 36 Tahun 2008 tentang Jenis 
dan Tarif Atas Jenis Penerimaan Negara Bukan Pajak Yang Berlaku Pada Badan Pengkajian dan Penerapan Teknologi. Untuk rencana pelaksanaan TMC di 10 provinsi teratas penghasil beras nasional dengan durasi di masing-masing lokasi selama 60 hari, total biaya yang dibutuhkan sebesar Rp. 68.534.400.000,00 (enam puluh delapan miliar lima ratus tiga puluh empat juta empat ratus ribu rupiah), sebagaimana dirinci dalam Tabel 3.4.

Tabel 3.4. Rincian Anggaran Biaya Pelaksanaan TMC

\begin{tabular}{|r|l|r|r|}
\hline No. & \multicolumn{1}{|c|}{ Lokasi } & Tarif per hari (Rp) & Tarif 60 hari (Rp) \\
\hline 1 & Jawa Barat & 113.443 .000 & 6.806 .580 .000 \\
\hline 2 & Jawa Timur & 113.883 .000 & 6.832 .980 .000 \\
\hline 3 & Jawa Tengah & 113.663 .000 & 6.819 .780 .000 \\
\hline 4 & Sulawesi Selatan & 115.093 .000 & 6.905 .580 .000 \\
\hline 5 & Sumatera Utara & 114.983 .000 & 6.898 .980 .000 \\
\hline 6 & Sumatera Selatan & 114.103 .000 & 6.846 .180 .000 \\
\hline 7 & Lampung & 114.103 .000 & 6.846 .180 .000 \\
\hline 8 & Sumatera Barat & 114.433 .000 & 6.865 .980 .000 \\
\hline 9 & Kalimantan Selatan & 115.093 .000 & 6.905 .580 .000 \\
\hline 10 & Banten & 113.443 .000 & 6.806 .580 .000 \\
\hline & & Total $=$ & 68.534 .400 .000 \\
\hline
\end{tabular}

Secara keseluruhan, kebutuhan biaya untuk melaksanakan kegiatan TMC dalam rangka mendukung ketahanan pangan nasional ini membutuhkan total anggaran sebesar Rp. 879.534.400.000,00 (delapan ratus tujuh puluh sembilan milyar lima ratus tiga puluh empat juta empat ratus ribu rupiah), dengan perincian sebagai berikut :

a) Pengadaan 5 unit pesawat CASA NC 212-200 $=$ Rp. $65.000 .000 .000,00 \times 5$

$=$ Rp. 325.000.000.000,00

b) Pengadaan 2 unit pesawat CASA CN 235

$=$ Rp. $220.000 .000 .000,00 \times 2$

= Rp. 440.000.000.000,00

c) Pengadaan airscooper, instalasi dan sertifikasi 7 unit pesawat ( 5 CASA 212-200 dan 2 CASA CN 235)

= Rp. 2.000.000.000.000,00 × 7

= Rp. 14.000.000.000,00

d) Peralatan pendukung TMC (radar. GPS. dII) = Rp. $\quad 50.000 .000 .000,00$

e) Biaya TMC 60 hari di 10 provinsi $=$ Rp. $\quad 68.534 .400 .000,00$

Total =Rp. 879.534.400.000,00

Jika besarnya total kebutuhan biaya pelaksanaan TMC di atas dibandingkan dengan hasil TMC seperti nilai estimasi dalam sub bab 3.4, maka diperoleh besarnya nilai manfaat untuk tahun pertama sebesar = $1: 7$.

Untuk tahun-tahun berikutnya nilai manfaat akan jauh lebih besar, yaitu:

$=$ Rp. 68.534.400.000,00 : Rp.

5.874.000.000.000,00

$=1: 85$.

\section{DAFTAR PUSTAKA}

Aldrian, E., and R. Susanto, 2003: Identification of three dominant rainfall regions within Indonesia and their relationship to sea surface temperature, Int. J. Clim., 23(12), 1435-1452.

Anggoro Udhoro K., 2012: Kebutuhan Inovasi Alsistan Budidaya Padi menuju Swasembada Pangan dan Swasembada Berkelanjutan. Seminar Nasional Mekanisasi Pertanian. Balai Besar Pengembangan Mekanisasi Pertanian. Kementerian Pertanian Republik Indonesia. Jakarta

Azdan D., 2012: Keynote Speech Direktur Pengairan dan Irigasi Badan Perencanaan Pembangunan Nasional (Bapennas) Pada Acara Seminar Masyarakat Hidrologi Indonesia Dalam Rangka Menyambut Hari Air Dunia 2012 "Adaptasi Perubahan Iklim dan Bencana Terhadap Ketahanan Pangan Dalam Rangka Pencapaian Target Surplus Beras 10 Juta Ton Tahun 2014" Jakarta. 20 Maret 2012. Masyarakat Hidrologi Indonesia. Jakarta.

BPPT UPT Hujan Buatan, 2007: Laporan Kegiatan Teknologi Modifikasi Cuaca Untuk Menunjang Program Peningkatan Produksi Beras 2 Juta Ton Tahun 2007 di Provinsi Jawa Barat. Jawa Tengah. Jawa Timur dan Lampung. Badan Pengkajian dan Penerapan Teknologi. Jakarta.

BPPT UPT Hujan Buatan, 2012: Laporan Kegiatan Pelaksanaan Teknologi Modifikasi Cuaca 
Untuk Pengisian Waduk Kaskade Citarum Tahun 2012. Badan Pengkajian dan Penerapan Teknologi. Jakarta.

Harijono Sri Woro B., 2012: Keynote Speech Kepala Badan Meteorologi. Klimatologi dan Geofisika (BMKG) Pada Acara Seminar Masyarakat Hidrologi Indonesia Dalam Rangka Menyambut Hari Air Dunia 2012 "Adaptasi Perubahan Iklim dan Bencana Terhadap Ketahanan Pangan Dalam Rangka PencapaianTarget Surplus Beras 10 Juta Ton Tahun 2014" Jakarta. 20 Maret 2012. Masyarakat Hidrologi Indonesia. Jakarta.

Sosiawan H. Subagnyono K., 2009: Strategi Pembagian Air Secara Proporsional Untuk Keberlanjutan Pemanfaatan Air. Jurnal Pengembangan Inovasi Pertanian 2(4). 2009 : 299 - 305. Balai Besar Penelitian dan Pengembangan Sumberdaya Lahan Pertanian. Bogor. 